\title{
PENGARUH PROFITABILITAS DAN RISIKO BISNIS TERHADAP DIVIDEND PAYOUT RATIO MELALUI LIKUIDITAS SEBAGAI VARIABEL MODERASI
}

\author{
Nadya Fernanda Salsabilla \\ Universitas Negeri Surabaya \\ nadyafernanda.s@gmail.com \\ Yuyun Isbanah \\ Universitas Negeri Surabaya \\ yuyunisbanah@unesa.ac.id
}

\begin{abstract}
Dividend policy is a decision in which a company to determine the level of profit to be retained and the level of profits distributed as dividends to shareholders. This research aims to analyze the influence of profitability and business risk on dividend payout ratio with liquidity as moderating variable in Property, Real Estate, and Building Construction sector companies that is listed on the Indonesia Stock Exchange for the 2015-2018 period. The type of this research is a quantitative research and uses secondary data from the annual report on IDX. The sample of this research is 18 companies chosen by purposive sampling method. The data analysis technique used is multiple linear regression and moderated regression analysis (MRA). The results show that profitability has a positive effect on the dividend payout ratio because companies can utilize assets optimally to increase profits. Business risk harms the dividend payout ratio because companies choose to strengthen the capital structure and develop the companies by utilizing profits and investments to reduce business risk. After all, debt cannot always be expected. Liquidity can moderate the relationship between profitability and business risk on dividend payout ratios because liquidity is a consideration to dividend distribution so that it can increase the number of dividends distributed.
\end{abstract}

Keywords: business risk; dividend payout ratio; liquidity; profitability.

\section{PENDAHULUAN}

Dividen merupakan bagian penting dalam suatu perusahaan karena memiliki daya tarik tersendiri bagi investor. Return yang tinggi pasti diinginkan oleh investor atas investasi yang dilakukannya. Apabila dividen yang dibagikan kecil, saham perusahaan menjadi tidak menarik lagi bagi investor (Halim, 2016). Hal ini menjadikan dividen sebagai salah satu pertimbangan dalam berinvestasi bagi para investor. Kebijakan dividen harus dilakukan dengan optimal untuk menciptakan kesejahteraan antara kepentingan perusahaan dan kepentingan investor. Dividend payout ratio menunjukkan besaran pembagian dividen atas laba bersih perusahaan. Dividen menggambarkan seberapa efisien perusahaan dalam pemanfaatan sumber keuangan perusahaan serta kemampuannya dalam menghasilkan keuntungan (Khan \& Ashraf, 2014). Kebijakan dividen juga bisa digunakan sebagai sinyal finansial perusahaan pada investor luar bahwa keadaan perusahaan sedang stabil serta memiliki prospek yang baik (Nwude \& Agbo, 2017).

Gambar 1 menunjukkan rata-rata pembagian dividend payout ratio pada sembilan sektor BEI periode 2015-2018. Pada grafik di atas, terdapat delapan sektor yang mengalami fluktuasi kecuali sektor property, real estate, and building construction yang konsisten meningkat setiap tahunnya. Pada sektor tersebut rata-rata pembagian dividend payout ratio periode 2015-2018 secara berturut-turut yaitu sebesar $23,92 \%, 27,71 \%, 28,00 \%$, dan $67,42 \%$.

Badan Pusat Statistik (BPS) mencatat pada tahun 2018 persentase rumah tangga yang memiliki akses hunian layak dan terjangkau di perkotaan tahun 2015 adalah 97,68\% dan tahun 2018 menjadi 98,55\% atau naik sebesar $0,87 \%$. Sementara itu, presentase rumah tangga yang memiliki akses hunian layak dan terjangkau di pedesaan tahun 2015 sebesar 87,99\% dan tahun 2018 menjadi 92,26\% atau naik menjadi $4,27 \%$. Hal ini disebabkan gencarnya pembangunan infrastruktur yang berdampak pada kinerja perusahaan konstruksi milik negara serta pembangunan infrastruktur khususnya di bidang transportasi 
Nadya Fernanda Salsabilla \& Yuyun Isbanah. Pengaruh Profitabilitas dan Risiko Bisnis terhadap Dividend Payout Ratio melalui Likuiditas sebagai Variabel Moderasi

yang sangat menunjang berkembangnya industri properti di Indonesia karena akses yang lebih mudah dijangkau dan jarak hunian terhadap transportasi massal merupakan faktor yang penting sebelum membeli hunian (Kompas.com, 2019).

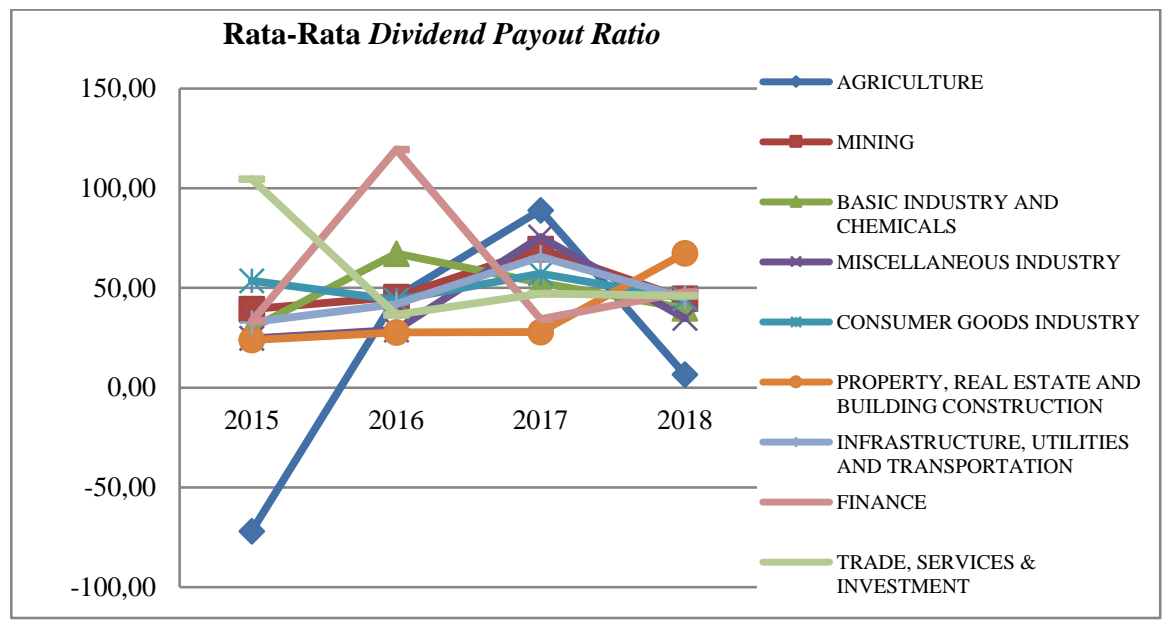

Sumber: idx.go.id (data diolah, 2019)

Gambar 1. GRAFIK RATA-RATA DIVIDEN PAYOUT RATIO PER SEKTOR 2015-2018

Pada 2015, kondisi perekonomian Indonesia mengalami penurunan dan merupakan yang terendah selama enam tahun terakhir yaitu sebesar $4,79 \%$. Penurunan ini dikarenakan melemahnya ekonomi dunia yang memberikan tekanan terhadap pertumbuhan ekonomi Indonesia. Perekonomian Indonesia tahun 2016 mulai naik menjadi 5,02\% dan di tahun 2017 perekonomian Indonesia kembali naik menjadi $5,07 \%$. Kemudian, perekonomian Indonesia kembali mengalami kenaikan lagi menjadi 5,17\% di tahun 2018 (bps.go.id, 2019). Hal ini tentu berdampak terhadap aktivitas perusahaan sehingga dapat juga mempengaruhi penentuan besaran dividend payout ratio (Lusiana \& Wijoyo, 2017).

Kebijakan dividen dipengaruhi beberapa faktor. Faktor pertama yaitu profitabilitas. Menurut Fitri et al. (2016), apabila perusahaan mampu meningkat laba dengan memanfaatkan seluruh asetnya, maka jumlah dividen juga akan meningkat. Ishaq et al. (2018) menjelaskan pengaruh profitabilitas terhadap kebijakan dividen adalah signifikan positif. Berbeda dengan Ahmed (2015) dan Demirgunes (2015) yang menjelaskan pengaruh profitabilitas terhadap kebijakan dividen yakni signifikan negatif Sedangkan menurut Khan \& Ashraf (2014) dan Mui \& Mazlina (2016), profitabilitas tidak berpengaruh terhadap kebijakan dividen.

Faktor kedua adalah risiko bisnis. Pembayaran dividen pada perusahaan berisiko bisnis tinggi akan lebih rendah untuk menghindari pengurangan dividen di masa mendatang (Epayanti \& Yadnya, 2014). Dalam penelitian Mnune \& Purbawangsa (2019) dan Jaara et al. (2018) menjelaskan pengaruh risiko bisnis terhadap kebijakan dividen adalah signifikan negatif. Berbeda menurut Halim (2016) dan Hudiwijono et al. (2018) menjelaskan pengaruh risiko bisnis terhadap kebijakan dividen adalah siginifikan positif. Sedangkan Khan \& Ahmad (2016) menjelaskan risiko bisnis tidak berpengaruh terhadap kebijakan dividen.

Faktor ketiga adalah likuiditas yaitu kemampuan melunasi seluruh kewajiban jangka pendek perusahaan (Kasmir, 2016:133). Likuiditas yang rendah dapat mengakibatkan rendahnya jumlah dividen yang dibagikan karena jumlah uang tunai yang kurang (Mui \& Mazlina, 2016). Hudiwijono et al. (2018) dan Olang et al. (2015) menjelaskan pengaruh signifikan positif antara likuiditas terhadap kebijakan dividen. Menurut Ishaq et al. (2018) dan Gayathridevi \& Mallikarjunappa (2012) menjelaskan bahwa pengaruh likuiditas terhadap kebijakan dividen adalah signifikan negatif. Sedangkan Lopolusi (2013) dan Thi \& Trang (2012) menjelaskan likuiditas tidak berpengaruh terhadap kebijakan dividen. 
Tolak ukur melunasi kewajiban jangka pendek perusahaan seperti pembagian dividen adalah likuiditas (Ningrum, 2017). Mirah et al. (2014), Hakeem \& Bambale (2016), dan Puspitaningtyas et al. (2019) menyebutkan bahwa likuiditas sebagai variabel moderasi memiliki pengaruh memperkuat atau mempelemah hubungan profitabilitas terhadap kebijakan dividen. Berbeda dengan Ningrum (2017) dan Yunisari \& Ratnadi (2018) menyebutkan bahwa likuiditas sebagai variabel moderasi tidak memiliki pengaruh memperkuat atau memperlemah hubungan profitabilitas terhadap kebijakan dividen.

Faktor penentu kebijakan dividen penelitian ini yaitu profitabilitas, risiko bisnis, serta likuiditas. Likuiditas digunakan sebagai variabel moderasi. Tujuan penelitian ini yaitu menganalisis pengaruh profitabilitas dan risiko bisnis terhadap dividend payout ratio, serta menganalisis pengaruh likuiditas sebagai variabel moderasi antara profitabilitas dan risiko bisnis terhadap dividend payout ratio.

\section{KAJIAN PUSTAKA DAN PENGEMBANGAN HIPOTESIS}

\section{Signalling Theory}

Signalling theory terkait dengan kebijakan dividen yaitu pembagian dividen merupakan sinyal bagi investor serta digunakan untuk mengurangi asimetri informasi. Modigliani dan Miller menjelaskan bahwa kenaikan dividen adalah sinyal bagi investor yang meramalkan penghasilan manajemen perusahaan di masa mendatang dalam kondisi yang lebih baik (Atmaja, 2008:287). Sehingga pembagian dividen akan meningkatkan keyakinan berinvestasi bagi para investor (Halim, 2016).

\section{Residual Dividend Theory}

Residual dividend theory menjelaskan bahwa sisa modal setelah mendanai investasi yang menguntungkan harus sama dengan jumlah pembagian dividen. Karakteristik kebijakan dividen yaitu: (1) mendanai investasi yang akan datang dengan mempertahankan rasio hutang optimum; (2) jika NPVnya positif maka investasi diterima; (3) menggunakan pendanaan internal untuk mendanai modal investasi baru, hanya setelah modal digunakan sepenuhnya, saham baru diterbitkan; (4) Jika setelah semua invetasi terdapat dana internal, maka dividen akan dibayarkan kepada investor (Keown et al, 2010:208).

\section{Dividend Payout Ratio}

Kebijakan dividen dapat menentukan besar kecilnya dividend payout ratio, yaitu besaran presentase laba bersih setelah pajak yang didistribusikan dalam bentuk dividen (Sudana, 2011:167). Dividen dapat dijadikan sebagai sinyal yang menggambarkan kondisi perusahaan yang sedang stabil dan memiliki prospek yang baik bagi investor (Nwude \& Agbo, 2017). Sehingga kondisi perusahaan dapat digambarkan melalui jumlah dividen yang dibagikan. Dividend payout ratio ditulis dengan rumus (1) sebagai berikut.

$D P R=\frac{\text { Dividen per Share }}{\text { Earning per Share }} \times 100 \%$

\section{Profitabilitas}

Profitabilitas adalah kemampuan perusahaan memanfaatkan seluruh aset perusahaan untuk menghasilkan laba (Sudana, 2011:22). Return On Assets (ROA) yaitu kemampuan perusahaan memanfaatkan seluruh asetnya untuk menghasilkan laba setelah pajak serta dinilai penting bagi perusahaan karena dapat menilai seberapa efektif dan efisiensi seluruh aset yang dapat dikelola oleh perusahaan (Sudana, 2011:22). Sehingga semakin tinggi kemampuan suatu perusahaan untuk mengolah asetnya menjadi laba, perusahaan cenderung akan membagikan dividen yang tinggi pula (Fitri et al., 2016). Return On Assets (ROA) ditulis dengan rumus (2) sebagai berikut.

$R O A=\frac{\text { EBIT }}{\text { Total Aset }} \times 100 \%$ 
Nadya Fernanda Salsabilla \& Yuyun Isbanah. Pengaruh Profitabilitas dan Risiko Bisnis terhadap

Dividend Payout Ratio melalui Likuiditas sebagai Variabel Moderasi

\section{Risiko Bisnis}

Risiko bisnis adalah ketidakpastian yang dapat mengakibatkan penurunan kinerja perusahaan karena kesulitan beroperasi dan ketidakamanan keuangan perusahaan (Mnune \& Purbawangsa, 2019). Perusahaan berisiko bisnis tinggi akan memperkuat struktur modalnya dengan menambah proporsi laba ditahan dan membayar dividen tinggi akan dihindari oleh perusahaan (Epayanti \& Yadnya, 2014). Pengukuran risiko bisnis dihitung menggunakan standar deviasi EBIT (Earning Before Interest \& Taxes) dibagi total aset (Mnune \& Purbawangsa, 2019). Risiko bisnis ditulis dengan rumus (3) sebagai berikut.

Risiko Bisnis $=\frac{\sigma \text { EBIT }}{\text { Total Aset }} \times 100 \%$

\section{Likuiditas}

Likuiditas adalah kemampuan melunasi kewajiban pada suatu perusahaan. Current Ratio yaitu kemampuan melunasi kewajiban jangka pendek perusahaan yang akan jatuh tempo (Kasmir, 2016:133). Dividen dibagikan dalam bentuk tunai, sehingga kas perusahaan harus cukup dan memadai (Keown, 2010:215). Sehingga pembagian dividen memiliki pengaruh terhadap likuiditas perusahaan. Current ratio ditulis dengan rumus (4) sebagai berikut:

Current Ratio $=\frac{\text { Total Aset Lancar }}{\text { Total Hutang Lancar }} \times 100 \%$

\section{Hubungan antar Variabel}

Pembagian dividen didasari atas kemampuan perusahaan menghasilkan laba yaitu profitabilitas. Sesuai dengan signalling theory yaitu pembagian dividen adalah sinyal perusahaan yang meramalkan prospek baik di masa mendatang, maka dibutuhkan aliran kas masuk yang tinggi untuk dapat menaikkan laba perusahaan. Apabila profitabilitas meningkat, maka dapat meningkatkan proposi laba yang digunakan untuk pembagian dividen. Tingginya kemampuan perusahaan dalam mengolah asetnya menjadi laba, cenderung membuat dividen yang dibagikan akan tinggi pula (Fitri et al., 2016). Hal ini didukung oleh Khan \& Ahmad (2016) dan Ishaq et al. (2018) yang menjelaskan pengaruh profitabilitas terhadap dividend payout ratio adalah signifikan positif.

H1: ROA berpengaruh positif terhadap dividend payout ratio pada perusahaan sektor property, real estate and building construction yang terdaftar di BEI tahun 2015-2018.

Salah satu faktor yang dapat mengurangi tingkat pembagian dividen yaitu risiko bisnis. Sejalan dengan karakteristik kebijakan dividen perusahaan yaitu mendanai investasi di masa mendatang dengan mempertahankan rasio hutang optimum, perusahaan dengan hutang yang banyak dapat meningkatkan rasio hutang perusahaan sehingga tingkat hutang optimum perlu ditetapkan untuk menghadapi risiko bisnis (Epayanti \& Yadnya, 2014). Risiko bisnis dapat dikurangi apabila perusahaan berisiko bisnis tinggi tidak menambah lagi jumlah hutang yang digunakan. Sehingga perusahaan berisiko bisnis tinggi memilih dividen yang rendah untuk dibagikan karena dana tersebut digunakan untuk mengembangkan perusahaan. Oleh karena itu, kewajiban membayar dividen tinggi akan dihindari perusahaan dengan risiko bisnis tinggi. Hal ini didukung oleh Mnune \& Purbawangsa (2019), Forti et al. (2015), dan Jaara et al. (2018) yang menjelaskan pengaruh risiko bisnis terhadap dividend payout ratio adalah signifikan negatif.

$\mathrm{H} 2$ : Risiko berpengaruh negatif terhadap dividend payout ratio pada perusahaan sektor property, real estate and building construction yang terdaftar di BEI tahun 2015-2018.

Salah satu faktor penting untuk mempertimbangkan keputusan besarnya pembayaran dividen adalah posisi likuiditas. Sesuai dengan karakteristik kebijakan dividen menurut residual dividend theory yaitu jika setelah semua investasi masih terdapat dana internal, maka dividen akan dibayarkan kepada investor. Jika semakin banyak dana internal setelah semua investasi, maka semakin besar pula jumlah pembagian dividen. Dividen merupakan arus kas keluar, apabila profitabilitas meningkat serta likuiditas perusahaan kuat maka pembagian dividen akan meningkat (Yunisari \& Ratnadi, 2018). Dividen akan 
dibagikan jika perusahaan dalam posisi likuid. Sehingga likuiditas memiliki pengaruh antara profitabilitas terhadap dividend payout ratio. Hal ini didukung oleh Puspitaningtyas et al. (2019) dan Hakeem \& Bambale (2016) yang menjelaskan bahwa likuiditas mampu memoderasi dan memperkuat pengaruh antara profitabilitas terhadap kebijakan dividen.

H3: Likuiditas dapat memoderasi pengaruh ROA terhadap dividend payout ratio pada perusahaan sektor property, real estate and building construction yang terdaftar di BEI tahun 2015-2018.

Perusahaan berisiko bisnis lebih memilih memanfaatkan dana internal untuk keperluan perusahaan. Sesuai dengan karakteristik kebijakan dividen menurut residual dividend theory yaitu jika setelah semua invetasi terdapat dana internal, maka dividen akan dibayarkan kepada investor. Perusahaan berisiko bisnis tinggi akan menggunakan laba untuk mengembangkan perusahaan dan setelah itu digunakan untuk membagikan dividen. Perusahaan akan pembagian dividen yang rendah agar dana internal yang dibutuhkan perusahaan terpenuhi sehingga tidak perlu lagi perusahaan mencari dana eksternal. Kemampuan perusahaan membagikan dividen tergantung pada arus kas (Musiega et al., 2013). Tingginya likuiditas dapat meningkatkan jumlah dividen (Puspitaningtyas et al., 2019). Sehingga perusahaan yang memiliki risiko bisnis tetap dapat membayar dividen jika tingkat likuiditas perusahaa dalam keadaan baik (Saputra, 2018). Hal ini didukung oleh Saputra (2018) yang menjelaskan bahwa likuiditas dapat memoderasi dan memperkuat risiko bisnis terhadap dividend payout ratio.

H4: Likuiditas dapat memoderasi pengaruh risiko bisnis terhadap dividend payout ratio pada perusahaan sektor property, real estate and building construction yang terdaftar di BEI tahun 2015-2018.

\section{METODE PENELITIAN}

Jenis penelitian ini adalah penelitian kuantitatif bersifat kausal (sebab-akibat). Data diambil dari data sekunder menggunakan teknik dokumentasi dari laman BEI dan laman perusahaan yang menjadi objek dan sampel penelitian. Populasi menggunakan seluruh perusahaan sektor property, real estate, and building construction yang terdaftar di BEI periode 2015-2018 menggunakan teknik purposive sampling dengan kriteria perusahaan yang menerbitkan laporan keuangan serta membagikan dividen secara berturut-turut selama periode 2015-2018. Perusahaan yang memenuhi kriteria sampel yaitu 18 perusahaan. Teknik analisis data yang digunakan adalah analisis regresi linier berganda dan Moderated Regression Analysis (MRA). Model regresi yang baik apabila memenuhi beberapa uji asumsi klasik yaitu uji normalitas, uji autokorelasi, uji multikolinearitas, uji heteroskedastisitas, dan uji linearitas. Model penelitian ini menggunakan Moderated Regression Analysis (MRA), maka harus membandingkan tiga persamaan regresi untuk menentukan jenis variabel moderatormya. Ketiga persamaan tersebut dalam dilihat pada rumus (5) (6) (7) sebagai berikut.

$Y=\alpha+\beta_{1} X_{1}+\beta_{2} X_{2}+\mathrm{e}$

$Y=\alpha+\beta_{1} X_{1}+\beta_{2} X_{2}+\beta_{3} Z_{i}+\mathrm{e}$

$Y=\alpha+\beta_{1} X_{1}+\beta_{2} X_{2}+\beta_{3} Z_{i}+\beta_{4} X_{1} * Z_{i}+\beta_{5} X_{2} * Z_{i}+\mathrm{e}$

Keterangan:

$\mathrm{Y}=$ Dividend Payout Ratio

$\alpha \quad=$ Konstanta

$\beta_{1}, \beta_{2}=$ Koefisien

$\mathrm{X}_{1}=$ Profitabilitas (ROA)

$\mathrm{X}_{2} \quad=$ Risiko Bisnis (RB)

$\mathrm{Zi} \quad=$ Likuiditas $(\mathrm{CR})$

$\mathrm{e} \quad=$ standard error 
Nadya Fernanda Salsabilla \& Yuyun Isbanah. Pengaruh Profitabilitas dan Risiko Bisnis terhadap Dividend Payout Ratio melalui Likuiditas sebagai Variabel Moderasi

\section{HASIL DAN PEMBAHASAN}

Teknik analisis data menggunakan uji asumsi klasik yang meliputi uji normalitas, uji autokorelasi, uji multikolonearitas, uji heterokedastisitas, dan uji linearitas. Kemudian dilanjutkan dengan menggunakan uji hipotesis yang meliputi uji statistik $\mathrm{F}$, uji statistik $\mathrm{T}$, moderated regression analysis (MRA), dan koefisien determinasi.

Tabel 1.

HASIL UJI ASUMSI KLASIK

\begin{tabular}{|c|c|c|c|c|c|c|}
\hline \multirow{2}{*}{ Variabel } & \multirow{2}{*}{$\begin{array}{l}\text { Normalitas } \\
\text { Sig. }\end{array}$} & \multirow{2}{*}{$\begin{array}{l}\text { Autokorelasi } \\
\text { Run Test }\end{array}$} & \multicolumn{2}{|c|}{ Multikolonearitas } & \multirow{2}{*}{$\begin{array}{l}\text { Heterokedastisitas } \\
\text { Sig. }\end{array}$} & \multirow{2}{*}{$\begin{array}{l}\text { Linearitas } \\
\text { R-Square }\end{array}$} \\
\hline & & & Tolerance & VIF & & \\
\hline & .200 & .106 & & & & .019 \\
\hline ROA & & & .926 & 1.080 & .632 & \\
\hline $\mathrm{RB}$ & & & .942 & 1.062 & .280 & \\
\hline SQRT_CR & & & .963 & 1.039 & .927 & \\
\hline
\end{tabular}

Sumber: Output SPSS (data diolah, 2020)

Hasil uji normalitas menggunakan uji Kolmogorov-Smirnov menunjukkan signifikansi sebesar 0,200 atau $>0,05$ yang menyatakan data berdistribusi secara normal. Hasil uji autokorelasi menggunakan run test menunjukkan signifikansi sebesar 0,106 atau > 0,05 yang artinya tidak terjadi autokorelasi. Hasil uji multikolinearitas menunjukkan semua variabel memiliki nilai $>0,10$ dan nilai VIF $<10$, yang menyatakan tidak terjadi multikolinieritas. Hasil uji heterokedastisitas menggunakan uji spearman menunjukkan semua variabel memiliki nilai signifikansi > 0,05 yang menyatakan tidak terjadi heteroskedastisitas. Hasil uji linieritas menggunakan uji lagrange multiplier memiliki nilai $\mathrm{c}^{2}$ hitung sebesar 1,064 dengan $\mathrm{c}^{2}$ tabel sebesar 69,83216. Karena $\mathrm{c}^{2}$ hitung $<\mathrm{c}^{2}$ tabel maka model penelitian lolos dari uji linearitas.

Tabel 2.

HASIL UJI HIPOTESIS

\begin{tabular}{llllll}
\hline & Jenis Uji & B & T & Sig & Keterangan \\
\hline Uji F & & & & .005 & Berpengaruh \\
& (Constant) & .152 & 4.482 & .000 & Berpengaruh \\
\multirow{2}{*}{ Uji T } & ROA & .562 & 2.272 & .027 & Berpengaruh \\
& RB & -.092 & -2.994 & .004 & Berpengaruh \\
\hline
\end{tabular}

Sumber: Output SPSS (data diolah, 2020)

Tabel 2 menunjukkan hasil uji $\mathrm{F}$ dengan nilai signifikansi 0,005 atau $<0,05$ yang menyatakan profitabilitas (ROA) dan risiko bisnis (RB) secara bersama (simultan) memiliki pengaruh terhadap dividend payout ratio. Hasil uji $\mathrm{T}$ menunjukkan ROA memiliki t hitung sebesar 2,272 dengan signifikansi sebesar 0,027 atau $<0,05$ yang artinya profitabilitas berpengaruh signifikan positif terhadap dividend payout ratio. $\mathrm{RB}$ memiliki t hitung sebesar -2,994 dengan signifikansi sebesar 0,004 atau < 0,05 yang artinya risiko bisnis berpengaruh signifikan negatif terhadap dividend payout ratio.

Tabel 3 menunjukkan persamaan (5) yaitu variabel ROA dan RB memiliki signifikansi sebesar 0,027 dan 0,004 atau signifikansinya $<0,05$ yang artinya berpengaruh signifikan. Persamaan (6) diketahui bahwa ROA, RB, dan SQRT_CR memiliki nilai signifikansi $<0,05$ yang artinya semua variabel signifikan.

Hasil uji moderasi persamaan (7) menunjukkan nilai signifikansi ROA dan RB di bawah 0,05 yang artinya signifikan. Sementara SQRT_CR memiliki signifikansi sebesar 0,281 atau > 0,05 yang artinya tidak signifikan. Kemudian nilai thitung ROA*SQRT_CR sebesar 2,485 yang berarti variabel moderasi memiliki pengaruh positif dengan signifikansi sebesar 0,016 atau $<0,05$ yang artinya SQRT_CR dapat memoderasi dan memperkuat variabel ROA terhadap DPR. Nilai t hitung RB*SQRT_CR sebesar 2,089 dengan signifikansi sebesar 0,042 atau $<0,05$ yang artinya SQRT_CR dapat memoderasi dan 
memperkuat variabel RB terhadap DPR. Berdasarkan persamaan (5) (6) (7) di atas, menunjukkan bahwa likuiditas (SQRT_CR) adalah variabel pure moderator. Di katakan variabel pure moderator apabila persamaan (5) dan (6) tidak berbeda secara signifikan, tetapi harus berbeda dengan persamaan (7) atau $(\beta 3=0 ; \beta 4 \neq \beta 5 \neq 0)$ (Ghozali, 2016:219).

Tabel 3.

RINGKASAN HASIL UJI MRA

\begin{tabular}{clrrr}
\hline Persamaan & \multicolumn{1}{c}{ Model } & \multicolumn{1}{l}{ B } & \multicolumn{1}{c}{ t } & \multicolumn{1}{l}{ Sig. } \\
\hline \multirow{2}{*}{5} & (Constant) & .152 & 4.482 & .000 \\
& ROA & .562 & 2.272 & .027 \\
& RB & -.092 & -2.994 & .004 \\
\hline \multirow{2}{*}{6} & (Constant) & .305 & 4.425 & .000 \\
& ROA & .654 & 2.743 & .008 \\
& RB & -.086 & -2.924 & .005 \\
& SQRT_CR & -.130 & -2.520 & .015 \\
\hline \multirow{6}{*}{7} & (Constant) & -.079 & -.375 & .709 \\
& ROA & 4.489 & 2.830 & .007 \\
& RB & -.437 & -2.471 & .017 \\
& SQRT_CR & .178 & 1.089 & .281 \\
& ROA*SQRT_CR & 3.115 & 2.485 & .016 \\
& RB*SQRT_CR & .304 & 2.089 & .042 \\
\hline Sumber: Output SPSS (2020,data diolah) & &
\end{tabular}

Sumber: Output SPSS (2020, data diolah)

Koefisien determinasi penelitian ini memiliki nilai Adjusted $R$ Square sebesar 0,295 yang artinya kemampuan model menerangkan variasi variabel dependen yang mampu dijelaskan variabel independen yang meliputi profitabilitas dan risiko bisnis yang dimoderasi dengan variabel likuiditas sebesar $29,5 \%$. Sedangkan sisanya yaitu $70,5 \%$ dijelaskan oleh variabel lain yang tidak diasumsikan dalam model penelitian ini.

\section{Pengaruh Profitabilitas terhadap Dividend Payout Ratio}

Hasil analisis data menunjukkan pengaruh profitabilitas terhadap dividend payout ratio adalah signifikan positif. Arah positif ini dapat menunjukkan bahwa meningkatnya profitabilitas dapat membuat perusahaan bersedia meningkatkan pembagian jumlah dividen. Hal ini terjadi karena perusahaan mampu meningkat laba dengan memanfaatkan seluruh asetnya, maka dividen yang dibagikan cenderung lebih tinggi. Profitabilitas merupakan faktor penting dalam pembagian dividen (Fitri et al., 2016). Hal ini didukung oleh Khan \& Ahmad (2016) dan Sari \& Handoyo (2013) yang menjelaskan bahwa profitabilitas berpengaruh signifikan positif terhadap dividend payout ratio.

Implikasi teoritis penelitian ini yaitu penelitian ini sejalan dengan signalling theory bahwa dividen adalah sinyal yang meramalkan tentang prospek dan kondisi perusahaan yang lebih baik di masa mendatang bagi investor. Perusahaan dengan prospek baik akan mengharapkan tingginya aliran kas yang masuk sehingga dapat meningkatkan laba. Jika laba perusahaan meningkat maka dapat meningkatkan jumlah laba untuk dividen. Sehingga laba perusahaan yang meningkatkan dapat meningkatkan dividen yang akan dibagikan pula.

Implikasi praktis penelitian ini yaitu perusahaan sektor property, real estate, and building construction harus memperhatikan profitabilitas karena dapat mempengaruhi dividend payout ratio. Upaya yang harus dilakukan perusahaan adalah memanfaatkan manajemen aset perusahaan secara optimal untuk meningkatkan laba perusahaan sehingga dapat meningkatkan jumlah dividen pula. Implikasi praktis bagi para investor adalah investor perlu memperhatikan ROA perusahaan karena berdasarkan hasil penelitian ini terdapat pengaruh antara ROA terhadap pembagian dividen yaitu jika ROA perusahaan naik maka pembagian dividen akan naik pula, begitupun sebaliknya. 
Nadya Fernanda Salsabilla \& Yuyun Isbanah. Pengaruh Profitabilitas dan Risiko Bisnis terhadap

Dividend Payout Ratio melalui Likuiditas sebagai Variabel Moderasi

\section{Pengaruh Risiko Bisnis terhadap Dividend Payout Ratio}

Hasil analisis data menunjukkan pengaruh risiko bisnis terhadap dividend payout ratio adalah signifikan negatif yang artinya tingginya risiko bisnis perusahaan dapat mengakibatkan rendahnya dividen yang dibagikan, begitupun sebaliknya. Hal ini disebabkan karena perusahaan memilih untuk mempertahankan modal serta mengembangkan usahanya dengan cara meningkatkan jumlah laba ditahan sehingga pembagian dividen cenderung rendah. Hal ini didukung penelitian Forti et al. (2015), Jaara et al. (2018), serta Ahmad \& Muqaddas (2016) yang menjelaskan risiko bisnis berpengaruh signifikan negatif terhadap dividend payout ratio.

Implikasi teoritis penelitian ini yaitu penelitian ini sejalan dengan karakteristik kebijakan dividen menurut residual dividend theory yaitu mendanai investasi di masa mendatang dengan mempertahankan rasio hutang optimum. Perusahaan yang menggunakan hutang lebih banyak daripada modal dapat meningkatkan rasio hutang perusahaan serta dapat mempersulit perusahaan dalam melunasi hutang tersebut. Jika hutang perusahaan semakin tinggi maka perusahaan akan memperkuat kondisi keuangan internal perusahaan dengan memanfaatkan laba ditahan menjadi sumber pendanaan internal sehingga mengakibatkan pembagian dividen akan lebih rendah.

Implikasi praktis penelitian ini yaitu perusahaan sektor property, real estate, and building construction harus mempertahan hutang optimal karena dapat menurunkan risiko bisnis perusahaan yang dapat meningkatkan pembagian dividen. Upaya yang harus dilakukan perusahaan adalah perusahaan harus menguatkan struktur modal terlebih dahulu dengan cara memanfaatkan laba dan investasi karena menggunakan hutang tidak selalu dapat diharapkan serta dapat meningkatkan risiko bisnis. Implikasi praktis bagi para investor adalah investor perlu memperhatikan risiko bisnis perusahaan karena naik turunnya risiko bisnis dapat memengaruhi pembagian dividen.

\section{Pengaruh Profitabilitas terhadap Dividend Payout Ratio dengan Likuiditas sebagai Variabel Moderasi}

Hasil pengujian menujukkan likuiditas mampu memoderasi dan memperkuat profitabilitas terhadap dividen payout ratio. Hal ini disebabkan karena dividen bersumber dari keuntungan perusahaan dengan likuiditas sebagai pertimbangan utama (Puspitaningtyas et al., 2019). Hal ini didukung oleh Hakeem \& Bambale (2016) dan Mirah et al. (2014) bahwa likuiditas mampu memoderasi profitabilitas terhadap dividend payout ratio.

Implikasi teoritis penelitian ini yaitu penelitian ini sesuai dengan karakteristik kebijakan dividen menurut residual dividend theory yaitu jika setelah semua investasi masih terdapat dana internal, maka dividen akan dibayarkan kepada investor. Jika semakin banyak dana internal setelah semua investasi, maka posisi likuiditas menjadi kuat sehingga dapat meningkatkan jumlah dividen. Dividen bisa dikatakan sebagai arus kas keluar perusahaan. Laba dan arus kas keluar merupakan hal yang berbeda, sehingga pembagian dividen harus menunjukkan tidak hanya laba perusahaan tetapi juga kemampuan perusahaan dalam membayar dividen.

Implikasi praktis penelitian ini yaitu perusahaan sektor property, real estate, and building construction harus memperhatikan kemampuan perusahaan menghasilkan laba serta arus kas karena hal tersebut merupakan kapasitas perusahaan untuk membayar dividen. Upaya yang harus dilakukan perusahaan adalah meningkatkan likuiditas, karena dividen cenderung dibagikan oleh perusahaan yang memiliki likuiditas kuat daripada perusahaan yang memiliki likuiditas rendah dengan tingkat profitabilitas yang sama. Implikasi praktis bagi investor adalah memperhatikan tingkat laba perusahaan dan posisi likuiditas perusahaan karena menjadi mempertimbangkan dalam menentukan keputusan besarnya dividen yang akan dibagikan.

\section{Pengaruh Risiko Bisnis terhadap Dividend Payout Ratio dengan Likuiditas sebagai Variabel Moderasi}

Hasil pengujian menujukkan bahwa likuiditas mampu memoderasi dan memperkuat risiko bisnis terhadap dividend payout ratio. Hal ini terjadi karena likuiditas menjadi salah satu pertimbangan serta penentu besar kecilnya jumlah dividen. Risiko adalah hal dapat mengurangi tingkat return bagi investor. 
Perusahaan dengan laba tinggi tidak selalu mempunyai kas yang cukup, sehingga diperlukan kas yang cukup untuk membagikan dividen (Puspitaningtyas et al., 2019). Hal ini didukung oleh Saputra (2018) bahwa likuiditas mampu memoderasi risiko bisnis terhadap dividend payout ratio.

Implikasi teoritis penelitian ini yaitu penelitian ini sesuai dengan karakteristik kebijakan dividen menurut residual dividend theory yaitu jika setelah semua investasi masih terdapat dana internal, maka dividen akan dibayarkan kepada investor. Perusahaan berisiko bisnis tinggi memilih menggunakan laba untuk mengembangkan perusahaannya dan setelah itu digunakan untuk membagikan dividen. Likuiditas yang memadai mampu meningkatkan kemampuan perusahaan untuk membagikan dividen.

Implikasi praktis penelitian ini adalah perusahaan sektor property, real estate, and building construction harus memperhatikan posisi likuiditas perusahaan, karena arus kas menjadi pertimbangan dalam menetapkan dividen yang akan dibayarkan. Upaya yang dilakukan perusahaan adalah meningkatkan likuiditas perusahaan karena perusahaan dengan risiko bisnis tetap dapat membagikan dividen jika kemampuan arus kas dalam keadaan baik. Implikasi praktis bagi investor adalah memperhatikan likuiditas perusahaan karena dapat mempengaruhi kemampuan yang dimiliki perusahaan untuk membagikan dividen.

\section{KESIMPULAN}

Profitabilitas memiliki pengaruh signifikan positif karena perusahaan mampu memanfaatkan aset perusahaan secara optimal untuk meningkatkan laba, sehingga dividen semakin meningkat. Risiko bisnis memiliki pengaruh signifikan negatif karena perusahaan berisiko bisnis tinggi memilih untuk menahan laba untuk menguatkan struktur modal serta mengembangkan perusahaannya sehingga dividen akan rendah. Likuiditas mampu memoderasi pengaruh profitabilitas terhadap dividend payout ratio karena pembagian dividen ditentukan terutama oleh kemampuannya untuk menghasilkan laba dan likuiditas yang memadai. Likuiditas mampu memoderasi pengaruh risiko bisnis terhadap dividend payout ratio karena perusahaan dengan risiko bisnis tinggi, tetap dapat membagikan dividen apabila kemampuan likuiditas dalam keadaan baik.

Bagi perusahaan, hendaknya memanfaatkan aset perusahaan secara optimal untuk meningkatkan laba perusahaan. Peningkatan laba dan investasi dapat dimanfaatkan untuk menguatkan struktur modal untuk mengurangi tingkat risiko bisnis. Perusahaan juga hendaknya meningkatkan likuiditas karena kemampuan arus kas perusahaan menjadi pertimbangan dalam pembagian dividen. Bagi investor sebaiknya memperhatikan terkait profitabilitas, risiko bisnis serta likuiditas perusahaan untuk mengetahui perkembangan perusahaan setiap tahunnya. Keterbatasan penelitian ini adalah kurangnya variabel independen yang digunakan sehingga kurangnya informasi terhadap variabel lain yang juga dapat mempengaruhi dividen. Saran bagi peneliti selanjutnya dengan mempertimbangkan hasil Adjusted $R$ Square penelitian ini, yaitu menambah variabel independen lain di luar penelitian yang dapat memengaruhi kebijakan dividen seperti ukuran perusahaan, leverage, kepemilikan manajerial, dan investment opportunity set.

\section{DAFTAR PUSTAKA}

Ahmed, I. E. (2015). Liquidity, Profitability and the Dividends Payout Policy. World Review of Business Research, 5(2), 73-85.

Atmaja, L. S. (2008). Teori dan Praktik Manajemen Keuangan (Edisi 1). Yogyakarta: ANDI.

Borges Forti, C. A., Peixoto, F. M., \& Lima E Alves, D. (2015). Determinant factors of dividend payments in Brazil. Revista Contabilidade $e$ Financas, 26(68), 167-180. https://doi.org/10.1590/1808-057x201512260 
Nadya Fernanda Salsabilla \& Yuyun Isbanah. Pengaruh Profitabilitas dan Risiko Bisnis terhadap

Dividend Payout Ratio melalui Likuiditas sebagai Variabel Moderasi

Bps.go.id. (2019). Persentase Rumah Tangga Yang Memiliki Akses Terhadap Hunian yang Layak Dan Terjangkau Menurut Daerah Tempat Tinggal, 2015 - 2018. (https://www.bps.go.id/dynamictable/2018/05/24/1365/persentase-rumah-tangga-yangmemiliki-akses-terhadap-hunian-yang-layak-dan-terjangkau-menurut-daerah-tempat-tinggal2015---2018.html, diakses pada 23 Oktober 2019)

Demirgunes, K. (2015). Determinants of target dividend payout ratio: A panel autoregressive distributed lag analysis. International Journal of Economics and Financial Issues, 5(2), 418-426.

Epayanti, Ayu; Yadnya, I. P. (2014). Pengaruh Ukuran Perusahaan dan Risiko Bisnis Terhadap Profitabilitas Serta Kebijakan Dividen. E-Jurnal Manajemen Universitas Udayana, 3(12), 3488 3502 .

Fitri, R. R., Hosen, M. N., \& Muhari, S. (2016). Analysis of Factors that Impact Dividend Payout Ratio on Listed Companies at Jakarta Islamic Index. International Journal of Academic Research in Accounting, Finance and Management Sciences, 6(2). https://doi.org/10.6007/ijarafms/v6$\underline{\mathrm{i} 2 / 2074}$

Gayathridevi, a, \& Mallikarjunappa, T. (2012). Dividend Policy of Indian Textile Companies - An Empirical Study. Contemporary Management Research, 6(2), 14-32.

Ghozali, I. (2016). Aplikasi Analisis Multivariete Dengan Program IBM SPSS 23 (Edisi 8). Semarang: Badan Penerbit Universitas Diponegoro.

Hakeem, S. A., \& Bambale, A. J. (2016). Mediating Effect of Liquidity on Firm Performance and Dividend Payout of Listed Manufacturing Companies in Nigeria. Journal of Chemical Information and Modeling, 53(9), 1689-1699. https://doi.org/10.1017/CBO9781107415324.004

Halim, J. J. (2016). Faktor-faktor yang Memengaruhi Kebijakan Deviden Perusahaan Yang Terdaftar di Bursa Efek Indonesia Pada Sektor Industri Barang Konsumsi Periode 2008-2011. Calyptra, 5(4), 1-19.

Hudiwijono, R. E. W., Aisjah, S., \& Ratnawati, K. (2018). Influence of fundamental factors on dividend payout policy : study on construction companies listed on Indonesian Stock Exchange. Wacana, 2l(1).

Ishaq, M., Amin, K., \& Khan, F. (2018). Factors Determining the Dividend Payout in the Cement Sector of Pakistan. Business Economics Management, 8(2), 171-186.

Jaara, B., Alashhab, H., \& Jaara, O. (2018). The Determinants of Dividend Policy for Non-Financial Companies in Jordan. International Journal of Economics and Financial Issues, 8(2), 198-209.

Kasmir. (2016). Analisis Laporan Keuangan (Edisi 1). Jakarta: PT Rajagrafindo.

Keown, A.J., Martin, J. D., Petty, j, W.,\& Scoot, D. F. J. (2010). Manajemen Keuangan : Prinsip dan Penerapan Jilid 2 (Edisi 10). Jakarta: Indeks.

Khan, F. A., \& Ahmad, N. (2016). Determinants of dividend payout: An empirical study of pharmaceutical companies of Pakistan stock exchange (PSE). Proceedings of the 28th International Business Information Management Association Conference - Vision 2020: Innovation Management, Development Sustainability, and Competitive Economic Growth, 2017, 869-888. https://doi.org/10.5171/2017.538821 
Khan, W., \& Ashraf, N. (2014). In Pakistani Service Industry: Dividend Payout Ratio as Function of some Factors. International Journal of Academic Research in Accounting, Finance and Management Sciences, 4(1), 390-396. https://doi.org/10.6007/ijarafms/v4-i1/696

Kompas.com. (2019). Pembangunan Infrastruktur Dongkrak Perkembangan Industri Properti. (https://ekonomi.kompas.com/read/2019/02/27/212639426/pembangunan-infrastrukturdongkrak-perkembangan-industri-properti, diakses pada 25 Januari 2020)

Lusiana, E., \& Wijoyo, D. S. (2017). Faktor-Faktor Yang Mempengaruhi Kebijakan Dividen Perusahaan Publik Non Keuangan. Jurnal Bisnis Dan Akuntansi, 3(2), 152-171.

Lopolusi, I. (2013). Analisis Faktor-Faktor Yang Memengaruhi Kebijakan Dividen Sektor Manufaktur Yang Terdaftar Di Pt Bursa Efek Indonesia Periode 2007-2011. Jurnal Ilmiah Mahasiswa Universitas Surabaya, 2(1), 1-12

Mirah, A. A. A., Devi, V., \& Suardikha, I. M. S. (2014). Kebijakan Dividen Dengan Likuiditas Sebagai Variabel Pemoderasi. E-Jurnal Ekonomi Dan Bisnis Universitas Udayana 3.12 (2014) : 702-717, $12,702-717$.

Mnune, T. D., \& Purbawangsa, I. B. A. (2019). Pengaruh Profitabilitas, Leverage, Ukuran Perusahaan Dan Risiko Bisnis Terhadap Kebijakan Dividen Pada Perusahaan Manufaktur. E-Jurnal $\begin{array}{llll}\text { Manajemen Universitas } & \text { Udayana, } & 8(5), & \end{array}$ https://doi.org/10.24843/ejmunud.2019.v08.i05.p10

Mui, Y. T., \& Mazlina, M. (2016). Determinants Of Dividend Payout Ratio: Evidence From Malaysian Government-Linked Companies (Glcs ). Journal of Applied Environmental and Biological Sciences, 6(March), 48-54.

Musiega, M. G., Alala, O. B., Douglas, M., Christopher, M. O., \& Robert, E. (2013). Determinants Of Dividend Payout Policy Among Non-Financial Firms On Nairobi Securities Exchange, Kenya. International Journal of Scientific \& Technology Research, 2(10), 253-266.

Ningrum, N. P. (2017). Determinan Kebijakan Dividen. Jurnal Akuntansi Multiparadigma, 8(3), 499510. https://doi.org/10.18202/jamal.2017.12.7069

Nwude, E. C., \& Agbo, E. I. (2017). Dividend Policy of Banks : The Nigerian Perspective. International Journal of Economic Perspectives, 11(4), 230-251.

Olang, Margaret Akinyi; Akenga, Grace malissa; Mwangi, J. K. (2015). Effect of Liquidity on the Dividend Pay-out by Firms Listed at the Nairobi Securities Exchange, Kenya. Science Journal of Business and Management, 3(5), 196. https://doi.org/10.11648/j.sjbm.20150305.18

Puspitaningtyas, Z., Prakoso, A., \& Masruroh, A. (2019). Pengaruh Profitabilitas Terhadap Kebijakan Dividen Dengan Likuiditas Sebagai Pemoderasi. Jurnal Administrasi Bisnis, 9(3), 1. https://doi.org/10.35797/jab.9.3.2019.25120.1-17

Saputra, L. F. (2018). Pengaruh Profitabilitas Dan Kebijakan Hutang Terhadap Kebijakan Dividen Dengan Likuiditas Sebagai Variabel Moderating. Jurnal Universitas Muhammdiyah Yogyakarta, $7,1-25$.

Sudana, I. M. (2011). Manajemen Keuangan Perusahaan Teori \& Praktik. Jakarta: Erlangga.

Yunisari, N. W., \& Ratnadi, N. M. D. (2018). Pengaruh Profitabilitas dan Kepemilikan Manajerial Pada Kebijakan Dividen dengan Likuiditas Sebagai Variabel Moderasi. E-Jurnal Akuntansi, 23, 379. https://doi.org/10.24843/eja.2018.v23.i01.p15 